九州大学学術情報リポジトリ

Kyushu University Institutional Repository

0ccurrences of radiolarian biostratigraphic markers Lychnocanoma nipponica sakai $i$ and Amphimelissa setosa in Core YK07-12 PC3B from the Okhotsk Sea

Ikenoue, Takahito

Department of Earth \& Planetary Sciences, Grraduate School of Sciences, Kyushu University

Takahashi, Kozo

Department of Earth \& Planetary Sciences, Grraduate School of Sciences, Kyushu University

Sakamoto, Tatsuhiko

Earth and Life History Research Program, Institute of Biogeosciences, Japan Agency for MarineEarth Science and Technology

Sakai, Saburo

Earth and Life History Research Program, Institute of Biogeosciences, Japan Agency for MarineEarth Science and Technology

他

https://doi.org/10.5109/19193

出版情報: 九州大学大学院理学研究院紀要 : Series D, Earth and planetary sciences. 32 (3), pp.110, 2011-03-10. Faculty of Science, Kyushu University

バージョン :

権利関係: 
Mem. Fac. Sci., Kyushu Univ., Ser. D, Earth \& Planet. Sci., Vol. XXXII, No. 3, pp. 1-10, March 10, 2011

\title{
Occurrences of radiolarian biostratigraphic markers Lychnocanoma nipponica sakaii and Amphimelissa setosa in Core YK07-12 PC3B from the Okhotsk Sea
}

\author{
Takahito Ikenoue*, Kozo Takahashi*, Tatsuhiko Sakamoto**, \\ Saburo Sakai** and Koichi Iijima**
}

\begin{abstract}
Core YK07-12 PC03B obtained from the central Okhotsk plain $\left(52^{\circ} 36^{\prime} \mathrm{N}, 150^{\circ} 08^{\prime} \mathrm{E}\right.$; water depth: 1049 $\mathrm{m})$ was analyzed every $5 \mathrm{~cm}$, focusing on two radiolarian biostratigraphic markers in the late Pleistocene: Lychnocanoma nipponica sakaii and Amphimelissa setosa. The last occurrence (LO) datum of A. setosa at $67 \mathrm{ka}$ conformed with those of the LO of the previously published studies. However, the LO of $L$. nipponica sakaii at $25 \mathrm{ka}$ was off set and significantly younger than those published in the previous studies in the North Pacific and the marginal seas. We introduce herein the conceptual use of the last common occurrence (LCO) of L. nipponica sakaii as the LCO conforms with the LO of this taxon published elsewhere and hence more reliable, especially out side of the northern part of the central Okhotsk plain. The LCO of L. nipponica sakaii is $46 \mathrm{ka}, 21 \mathrm{kyrs}$ older than the LO, but is approximately the same as the LOs published elsewhere. We postulate the LCO as a practical datum which can be compared with the data from out side of the studied region. As alternative explanations, the obtained significantly younger LO than the LOs of other studies from the out side of the study region may stem from the following two reasons. Because that the present study is specifically focused on the two biostratigraphic marker radiolarian taxa with details our microscopic counts are significantly greater than those performed in the previous studies. This may have caused the documentation of the LO with the rare microscopic counts on multiple microslides, which could have been missed had we counted only one microslide. It is also possible that the effect of bioturbation due to upward transport in the slow sedimentation rate regime caused the appearance of the rare specimens of L. nipponica sakaii well above the LCO.
\end{abstract}

Keywords: Radiolarian biostratigraphy, last occurrence (LO), last common occurrence (LCO), Lychnocanoma nipponica sakaii, Amphimelissa setosa, Okhotsk Sea, late Pleistocene

\section{Introduction}

The Okhotsk Sea represents as one of the lowest latitude regions with extensive sea-ice cover in the world. Environmental conditions of the Okhotsk Sea with such sea-ice formation can alter global water circulations because that the formation results in the generation of dense Okhotsk intermediate water which exits into the North Pacific (e.g., Talley, 1991). The Okhotsk Sea is also characterized by a high biological productivity and thus it serves as an efficient biological pump to absorb atmospheric $\mathrm{CO}_{2}$. Therefore, for further understanding the global carbon cycle it is important to study the region including the past environmental conditions (Takahashi, 1998).

Radiolarians represent as one of the common microzooplankton groups in the pelagic and hemipelagic realms. Their siliceous skeletons are often well preserved in the sediments and hence they can be used in biostratigraphy

Manuscript received on 1 November 2010; accepted on 7 January 2011

* Department of Earth \& Planetary Sciences, Graduate School of Sciences, Kyushu University, 6-10-1 Hakozaki, Higashi-ku, Fukuoka 812-8581, JAPAN; Corresponding author’s e-mail: ikenoue@geo.kyushu-u.ac.jp

** Earth and Life History Research Program, Institute of Biogeosciences, Japan Agency for Marine-Earth Science and Technology (JAMSTEC), Natsushima-cho 2-15, Yokosuka, 237-0061, JAPAN 
of deep-sea sediments and reconstruction of paleoceanographic conditions. Pertinent previous works on radiolarian biostratigraphy in the Okhotsk Sea are, for example, published by Takahashi et al. (2000), Matul et al. (2002, 2009), and Okazaki et al. (2003, 2005). The purpose of this study is to examine radiolarian biostratigraphic markers of the late Pleistocene in detail employing Core YK07-12 PC03B obtained in the northern part of the central Okhotsk plain.

\section{Materials and Methods}

During Cruise YK07-12 of R/V Yokosuka belonging to Japan Agency for Marine-Earth Science and Technology (JAMSTEC) in summer 2007, Core YK07-12 PC03B was obtained from the northern part of the central Okhotsk plain $\left(52^{\circ} 36^{\prime} \mathrm{N}, 150^{\circ} 08^{\prime} \mathrm{E}\right.$; water depth: 1,049 m; Fig. 1). The recovered core length is $14.09 \mathrm{~m}$. Sediment samples were continuously sliced every $1 \mathrm{~cm}$ in thickness throughout the core. In this study, samples were analyzed at every $5 \mathrm{~cm}$ interval.

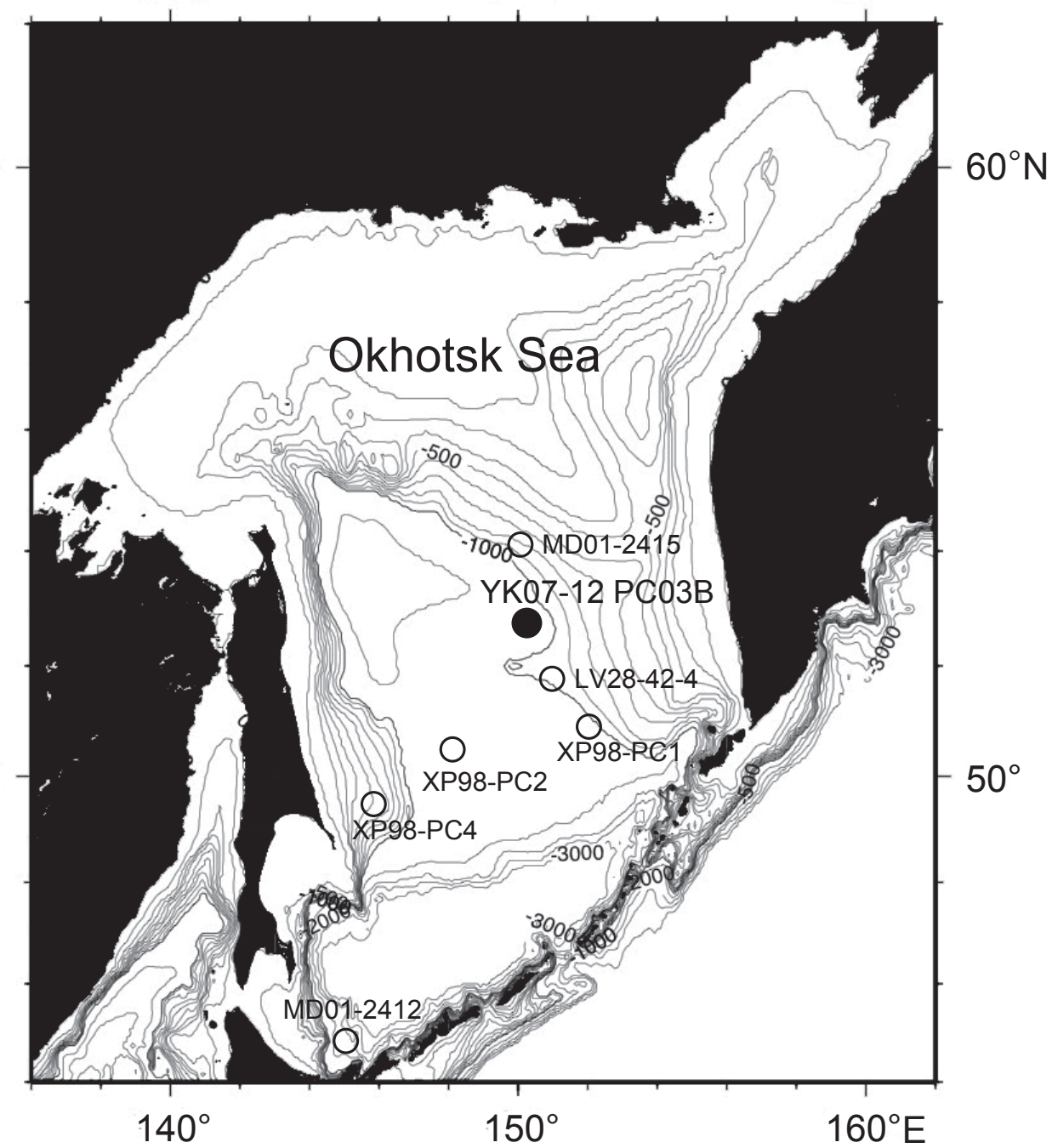

Fig. 1. Location map of Core YK07-12 PC03B (solid circle) together with other relevant cores (open circles) in the Okhotsk Sea. 
An age model of Core YK07-12 PC3B was established based on $\delta^{18} \mathrm{O}$ stratigraphy with subordinate magnetic susceptibility (MS). Graphic correlations of $\delta^{18} \mathrm{O}$ records were established between the $\delta^{18} \mathrm{O}$ variations of benthic foraminifer shells (Uvigerina spp.) in Core PC3B and the standard curve of LR04 Benthic $\delta^{18} \mathrm{O}$ global stack constructed by Lisiecki and Raymo (2005) (Fig. 2). As results of the analyses, Marine Isotope Stages (MIS) 1-12.3 were identified, and it was determined that Core PC3B recorded at least 450 kyrs of the environmental conditions of the northern part of the central Okhotsk plain.

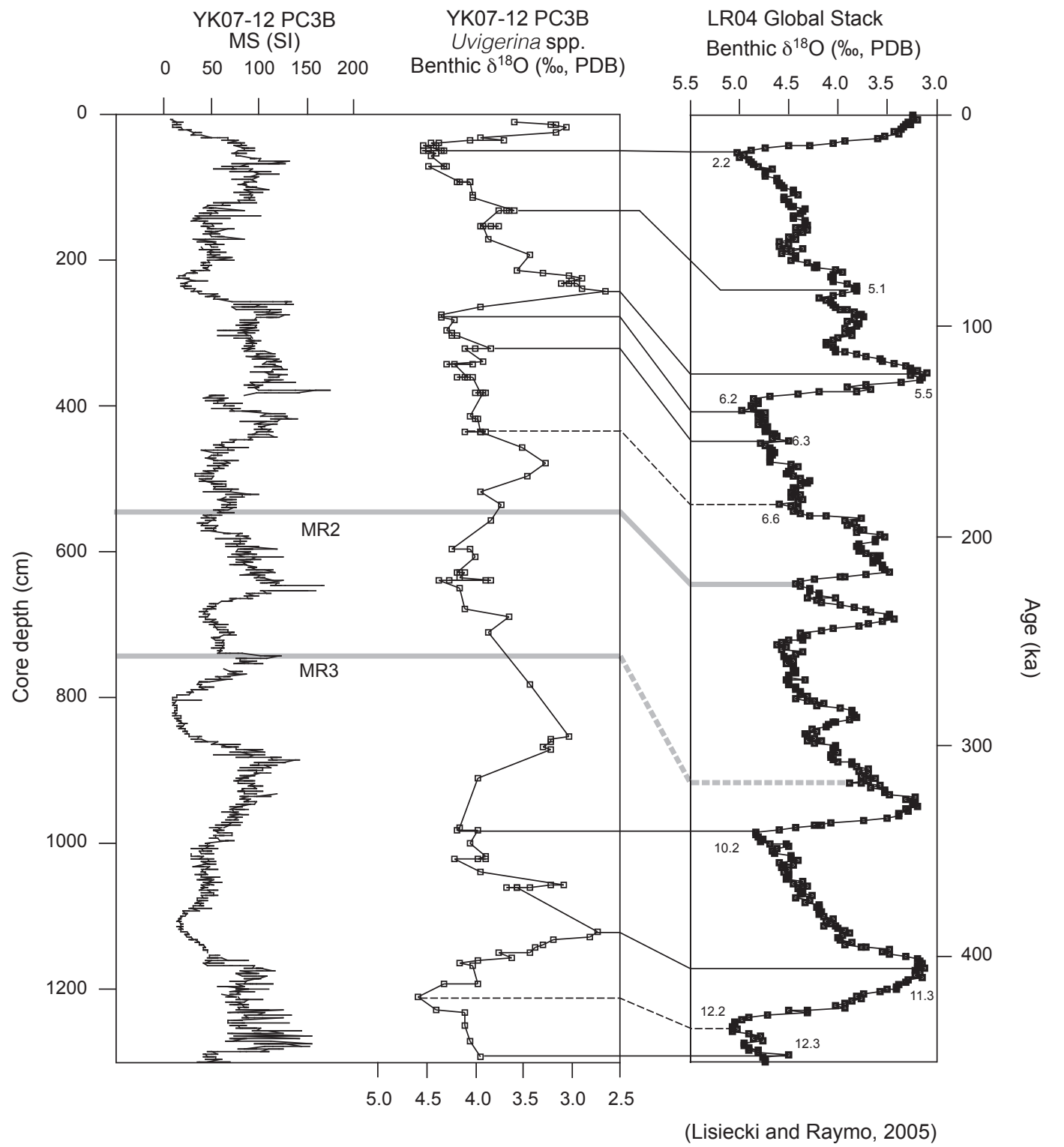

Fig. 2. An age model of Core YK07-12 PC3B based on $\delta^{18} \mathrm{O}$ stratigraphy and subordinated by MS. Changes in (a) MS of Core YK07-12-PC3B; (b) benthic foraminiferal (Uvigerina spp.) $\delta^{18} \mathrm{O}$ of Core YK07-12-PC3B; and (c) stacked benthic foraminiferal oxygen isotope curve LR04 (Lisiecki and Raymo, 2005), Lines MR2 and MR3 are tephra horizons recovered in Core YK07-12 PC3B. 
Radiolarian counts were conducted on 53 selected samples whose ages ranged from $133 \mathrm{ka}$ at $264.5 \mathrm{~cm}$ depth to the present at the core top. Wet samples of 100-1,100 mg were weighed after freeze-drying for $24 \mathrm{hrs}$. They were treated with $5 \mathrm{ml}$ of $1 \mathrm{~N}$ hydrochloric acid, $10 \mathrm{ml}$ of $30 \%$ hydrogen peroxide, and heated on a hot plate at $90^{\circ} \mathrm{C}$ for $1 \mathrm{hr}$ in order to remove organic matter and calcium carbonate. Then, Calgon ${ }^{\circledR}$ (hexametaphosphate, surfactant) solution was added to the mixture to further disaggregate the sediments. Our samples contained a large amount of lithogenic grains and thus we employed the elutriation method for extracting opal particles from the residues according to Itaki (2003). After the elutriation, samples were sieved through a stainless screen with 45 $\mu \mathrm{m}$ mesh and filtered through Gellman ${ }^{\circledR}$ membrane filters with a nominal pore size of $0.45 \mu \mathrm{m}$. The filtered samples were washed with distilled water to remove salts, dried in an oven at $50^{\circ} \mathrm{C}$, and then permanently mounted with Canada Balsam ${ }^{\circledR}$ on microslides. We counted the number of all radiolarian specimens on the slides under a compound light-microscope at x100-200 magnifications. Normally, counts were made on an entire area of

Table 1. Radiolarian counts in Core YK07-12 PC3B.

\begin{tabular}{|c|c|c|c|c|c|c|c|c|c|c|c|c|c|c|c|c|}
\hline \multirow[b]{2}{*}{ Section } & \multirow[b]{2}{*}{$\begin{array}{l}\text { Total depth } \\
\text { at cube } \\
\text { center }(\mathrm{cm})\end{array}$} & \multirow[b]{2}{*}{$\begin{array}{l}\text { Age } \\
\text { (ka) }\end{array}$} & \multirow[b]{2}{*}{$\begin{array}{l}\text { Dry bulk } \\
\text { density } \\
\left(\mathrm{g} \mathrm{cm}^{-3}\right)\end{array}$} & \multirow[b]{2}{*}{$\underset{\left(\mathrm{cm} \mathrm{ky}{ }^{-1}\right)}{\mathrm{SR}}$} & \multirow[b]{2}{*}{$\begin{array}{c}\text { Dry } \\
\text { sediment } \\
\text { (g) }\end{array}$} & \multirow[b]{2}{*}{$\begin{array}{l}\text { Number } \\
\text { of slides } \\
\text { counted }\end{array}$} & \multicolumn{2}{|c|}{ Total Radiolaria } & \multicolumn{3}{|c|}{ Lychnocanoma nipponika sakaii } & \multicolumn{4}{|c|}{ Amphimelissa setosa } & \multirow[b]{2}{*}{$\begin{array}{l}\text { Specimens } \\
\left(\mathrm{g} \text { dry sed. } .^{-1}\right)\end{array}$} \\
\hline & & & & & & & Count & $\begin{array}{c}\text { AR } \\
\left.\text { (No. rads } \mathrm{cm}^{2} k \mathrm{y}^{\prime}\right)\end{array}$ & Count & $\begin{array}{c}\text { AR } \\
\left.\text { (No. } \operatorname{rads}^{2} \mathrm{~cm}^{2} \mathrm{ky} \mathrm{y}^{\prime}\right)\end{array}$ & $\%$ & $\begin{array}{l}\text { Specimens } \\
\left(\mathrm{g} \text { dry sed } .^{-1}\right)\end{array}$ & Count & $\begin{array}{c}\text { AR } \\
\left.\text { (No. rads } \mathrm{cm}^{2} k y^{1}\right)\end{array}$ & $\%$ & \\
\hline 1 & 9.3 & 0.00 & 0.324 & 2.49 & 0.042 & 1 & 434 & 8381 & 0 & 0 & 0 & 0 & 0 & 0 & 0 & 0 \\
\hline 1 & 16.0 & 2.79 & 0.459 & 2.49 & 0.040 & 1 & 630 & 17896 & 0 & 0 & 0 & 0 & 0 & 0 & 0 & 0 \\
\hline 1 & 20.5 & 5.59 & 0.564 & 2.49 & 0.043 & 1 & 563 & 18559 & 0 & 0 & 0 & 0 & 0 & 0 & 0 & 0 \\
\hline 1 & 25.0 & 8.38 & 0.617 & 2.49 & 0.050 & 1 & 323 & 9901 & 0 & 0 & 0 & 0 & 0 & 0 & 0 & 0 \\
\hline 1 & 29.5 & 11.18 & 0.526 & 2.49 & 0.051 & 1 & 130 & 3374 & 0 & 0 & 0 & 0 & 0 & 0 & 0 & 0 \\
\hline 1 & 34.0 & 13.97 & 0.742 & 2.49 & 0.057 & 1 & 168 & 5418 & 0 & 0 & 0 & 0 & 0 & 0 & 0 & 0 \\
\hline 1 & 40.9 & 16.76 & 0.976 & 2.49 & 0.096 & 1 & 34 & 860 & 0 & 0 & 0 & 0 & 0 & 0 & 0 & 0 \\
\hline 1 & 45.4 & 19.69 & 1.010 & 1.43 & 0.118 & 1 & 79 & 970 & 0 & 0 & 0 & 0 & 0 & 0 & 0 & 0 \\
\hline 1 & 50.0 & 23.16 & 1.005 & 1.43 & 0.413 & 4 & 282 & 981 & 0 & 0 & 0 & 0 & 0 & 0 & 0 & 0 \\
\hline 1 & 54.5 & 26.63 & 0.968 & 1.43 & 0.420 & 4 & 426 & 1404 & 1 & 3 & 0 & 2 & 0 & 0 & 0 & 0 \\
\hline 1 & 59.1 & 30.10 & 1.057 & 1.43 & 0.982 & 8 & 721 & 1110 & 4 & 6 & 0.55 & 4 & 0 & 0 & 0 & 0 \\
\hline 1 & 66.0 & 33.57 & 1.045 & 1.43 & 0.408 & 3 & 561 & 2055 & 12 & 44 & 2.14 & 29 & 0 & 0 & 0 & 0 \\
\hline 1 & 70.6 & 37.03 & 1.002 & 1.43 & 0.419 & 2 & 1382 & 4727 & 2 & 7 & 0 & 5 & 0 & 0 & 0 & 0 \\
\hline 1 & 75.2 & 40.50 & 0.957 & 1.43 & 0.427 & 2 & 1600 & 5134 & 2 & 6 & 0 & 5 & 0 & 0 & 0 & 0 \\
\hline 1 & 79.3 & 43.97 & 1.058 & 1.43 & 0.095 & 1 & 239 & 3819 & 3 & 48 & 1.26 & 32 & 0 & 0 & 0 & 0 \\
\hline 2 & 79.3 & 44.66 & 1.002 & 1.43 & 0.096 & 1 & 192 & 2861 & 0 & 0 & 0 & 0 & 0 & 0 & 0 & 0 \\
\hline 2 & 84.8 & 48.13 & 1.020 & 1.43 & 0.441 & 2 & 972 & 3218 & 89 & 295 & 9.16 & 202 & 0 & 0 & 0 & 0 \\
\hline 2 & 89.4 & 51.60 & 0.938 & 1.43 & 0.491 & 5 & 326 & 891 & 222 & 606 & 68.10 & 452 & 0 & 0 & 0 & 0 \\
\hline 2 & 94.0 & 55.07 & 0.967 & 1.43 & 0.527 & 5 & 252 & 661 & 122 & 320 & 48.41 & 231 & 0 & 0 & 0 & 0 \\
\hline 2 & 100.9 & 58.54 & 0.966 & 1.43 & 0.452 & 8 & 309 & 945 & 195 & 596 & 63.11 & 432 & 0 & 0 & 0 & 0 \\
\hline 2 & 105.5 & 62.01 & 0.914 & 1.43 & 0.407 & 3 & 590 & 1894 & 335 & 1075 & 56.78 & 823 & 0 & 0 & 0 & 0 \\
\hline 2 & 110.1 & 65.47 & 0.946 & 1.43 & 0.071 & 1 & 122 & 2331 & 35 & 669 & 28.69 & 494 & 0 & 0 & 0 & 0 \\
\hline 2 & 114.7 & 68.94 & 1.151 & 1.43 & 0.139 & 1 & 189 & 2235 & 32 & 378 & 16.93 & 230 & 1 & 12 & 0.53 & 7 \\
\hline 2 & 119.2 & 72.41 & 0.730 & 1.43 & 0.066 & 1 & 232 & 3670 & 38 & 601 & 16.38 & 576 & 0 & 0 & 0 & 0 \\
\hline 2 & 126.1 & 75.88 & 0.700 & 1.43 & 0.058 & 1 & 305 & 5304 & 56 & 974 & 18.36 & 972 & 2 & 35 & 0.66 & 35 \\
\hline 2 & 130.6 & 79.20 & 0.706 & 1.43 & 0.057 & 1 & 279 & 4979 & 60 & 1071 & 21.51 & 1060 & 2 & 36 & 0.72 & 35 \\
\hline 2 & 135.2 & 81.15 & 0.493 & 2.5 & 0.027 & 1 & 223 & 10294 & 41 & 1893 & 18.39 & 1536 & 4 & 185 & 1.79 & 150 \\
\hline 2 & 139.8 & 83.10 & 0.566 & 2.5 & 0.049 & 1 & 357 & 10352 & 63 & 1827 & 17.65 & 1291 & 3 & 87 & 0.84 & 61 \\
\hline 2 & 144.4 & 85.06 & 0.619 & 2.5 & 0.046 & 1 & 359 & 12211 & 44 & 1497 & 12.26 & 967 & 1 & 34 & 0.28 & 22 \\
\hline 2 & 149.0 & 87.01 & 0.584 & 2.5 & 0.043 & 1 & 194 & 6522 & 25 & 840 & 12.89 & 576 & 4 & 134 & 2.06 & 92 \\
\hline 2 & 155.9 & 88.97 & 0.652 & 2.5 & 0.060 & 1 & 495 & 13505 & 48 & 1310 & 9.70 & 804 & 2 & 55 & 0.40 & 34 \\
\hline 2 & 160.5 & 90.92 & 0.502 & 2.5 & 0.062 & 1 & 631 & 12741 & 56 & 1131 & 8.87 & 900 & 19 & 384 & 3.01 & 305 \\
\hline 2 & 165.1 & 92.88 & 0.578 & 2.5 & 0.056 & 1 & 476 & 12328 & 71 & 1839 & 14.92 & 1272 & 7 & 181 & 1.47 & 125 \\
\hline 2 & 169.7 & 94.83 & 0.622 & 2.5 & 0.056 & 1 & 322 & 8926 & 71 & 1968 & 22.05 & 1266 & 7 & 194 & 2.17 & 125 \\
\hline 2 & 174.3 & 96.79 & 0.665 & 2.5 & 0.064 & 1 & 309 & 8085 & 33 & 863 & 10.68 & 520 & 9 & 235 & 2.91 & 142 \\
\hline 3 & 178.9 & 98.94 & 0.724 & 2.5 & 0.051 & 1 & 366 & 12984 & 38 & 1348 & 10.38 & 745 & 9 & 319 & 2.46 & 176 \\
\hline 3 & 184.6 & 100.89 & 0.659 & 2.5 & 0.067 & 1 & 331 & 8206 & 6 & 149 & 1.81 & 90 & 11 & 273 & 3.32 & 165 \\
\hline 3 & 189.0 & 102.85 & 0.595 & 2.5 & 0.052 & 1 & 790 & 22408 & 24 & 681 & 3.04 & 458 & 42 & 1191 & 5.32 & 802 \\
\hline 3 & 195.8 & 104.80 & 0.740 & 2.5 & 0.058 & 1 & 804 & 25809 & 22 & 706 & 2.74 & 382 & 50 & 1605 & 6.22 & 868 \\
\hline 3 & 200.2 & 106.75 & 0.626 & 2.5 & 0.063 & 1 & 2166 & 53544 & 23 & 569 & 1.06 & 363 & 149 & 3683 & 6.88 & 2354 \\
\hline 3 & 204.8 & 108.71 & 0.588 & 2.5 & 0.061 & 1 & 2522 & 60421 & 18 & 431 & 0.71 & 293 & 199 & 4768 & 7.89 & 3241 \\
\hline 3 & 209.4 & 110.66 & 0.575 & 2.5 & 0.064 & 1 & 4001 & 89649 & 26 & 583 & 0.65 & 405 & 642 & 14385 & 16.05 & 10000 \\
\hline 3 & 214.1 & 112.62 & 0.518 & 2.5 & 0.037 & 1 & 3002 & 104436 & 36 & 1252 & 1.20 & 968 & 578 & 20108 & 19.25 & 15538 \\
\hline 3 & 221.1 & 114.57 & 0.510 & 2.5 & 0.046 & 1 & 2810 & 78002 & 30 & 833 & 1.07 & 654 & 506 & 14046 & 18.01 & 11024 \\
\hline 3 & 225.7 & 116.53 & 0.585 & 2.5 & 0.049 & 1 & 2925 & 87846 & 26 & 781 & 0.89 & 534 & 470 & 14115 & 16.07 & 9651 \\
\hline 3 & 230.3 & 118.48 & 0.561 & 2.5 & 0.033 & 1 & 1939 & 81672 & 27 & 1137 & 1.39 & 811 & 203 & 8551 & 10.47 & 6096 \\
\hline 3 & 234.9 & 120.44 & 0.601 & 2.5 & 0.043 & 1 & 1651 & 58251 & 22 & 776 & 1.33 & 516 & 86 & 3034 & 5.21 & 2019 \\
\hline 3 & 239.5 & 122.41 & 0.626 & 2.5 & 0.056 & 1 & 1367 & 37905 & 14 & 388 & 1.02 & 248 & 111 & 3078 & 8.12 & 1968 \\
\hline 3 & 244.1 & 124.44 & 0.638 & 1.85 & 0.059 & 1 & 557 & 11132 & 5 & 100 & 0.90 & 85 & 48 & 959 & 8.62 & 812 \\
\hline 3 & 250.9 & 126.47 & 0.687 & 1.85 & 0.059 & 1 & 762 & 16461 & 9 & 194 & 1.18 & 153 & 45 & 972 & 5.91 & 765 \\
\hline 3 & 255.5 & 128.50 & 0.917 & 1.85 & 0.081 & 1 & 421 & 8875 & 8 & 169 & 1.90 & 99 & 46 & 970 & 10.93 & 571 \\
\hline 3 & 260.0 & 130.53 & 0.973 & 1.85 & 0.101 & 1 & 278 & 4934 & 7 & 124 & 2.52 & 69 & 21 & 373 & 7.55 & 207 \\
\hline 3 & 264.5 & 132.56 & 1.021 & 1.85 & 0.076 & 1 & 344 & 8582 & 3 & 75 & 0.87 & 40 & 22 & 549 & 6.40 & 291 \\
\hline
\end{tabular}


one microslide with a goal of counting $>300$ specimens. The counts of $<200$ specimens were resulted in eight cases out of the total of 55 cases whereas the counts exceeding 500 specimens resulted in 22 cases ( 11 cases $>1,000$ specimens) (Table 1). In two extremely cases of rare radiolarian occurrences (Samples $59.1 \mathrm{~cm}$ and $100.9 \mathrm{~cm}$ ) eight microslides were prepared and all the slides were counted in order to fulfill the initial goal of counting sufficient number of specimens. In order to achieve the goal as close as possible, multiple microslides were counted in eleven cases in total (Table 1). The classification of Lychnocanoma nipponica (Nakaseko) sakaii (Morley and Nigrini) and Amphimelissa setosa (Cleve) in the samples follow that of Morley and Nigrini (1995) for the former and Bjørklund et al. for the latter (1998), respectively.

A radiolarian accumulation rate (RAR) was calculated using the following equation: RAR (No. radiolarians $\left.\mathrm{cm}^{-2} \mathrm{kyr}^{-1}\right)=\left[\right.$ No. radiolarians $\mathrm{g}^{-1}$ dry sediment] $\left(\right.$ No. $\left.\mathrm{g}^{-1}\right) \times\left[\right.$ dry bulk density] $\left(\mathrm{g} \mathrm{cm}^{-3}\right) \times$ [sedimentation rate] $(\mathrm{cm}$ $\left.\mathrm{kyr}^{-1}\right)$. Dry bulk density was determined from weights of each of $10 \mathrm{cc}$ sediment samples taken with a polypropylene cube. It was calculated from the wet bulk density multiplied by the water contents (\%). The water contents of each sample were determined from weights of the wet and dry samples. The samples were weighed before and after drying in an oven at $50^{\circ} \mathrm{C}$ for $24 \mathrm{hrs}$. Sedimentation rates (SR) were assumed between the age control points.

\section{Results and Discussion}

The temporal changes in total RAR in Core YK07-12 PC3B are shown in Fig. 3. Its pattern tends to follow the temporal patterns displayed by the global $\delta^{18} \mathrm{O}$ changes during the glacial-interglacial cycles (e.g., Lisiecki and Raymo, 2005); total RAR increased during the interglacial periods and decreased during the glacial periods at least for the time span examined. The values during MIS 1 and MIS 5 were relatively high compared to those of the other MIS stages.

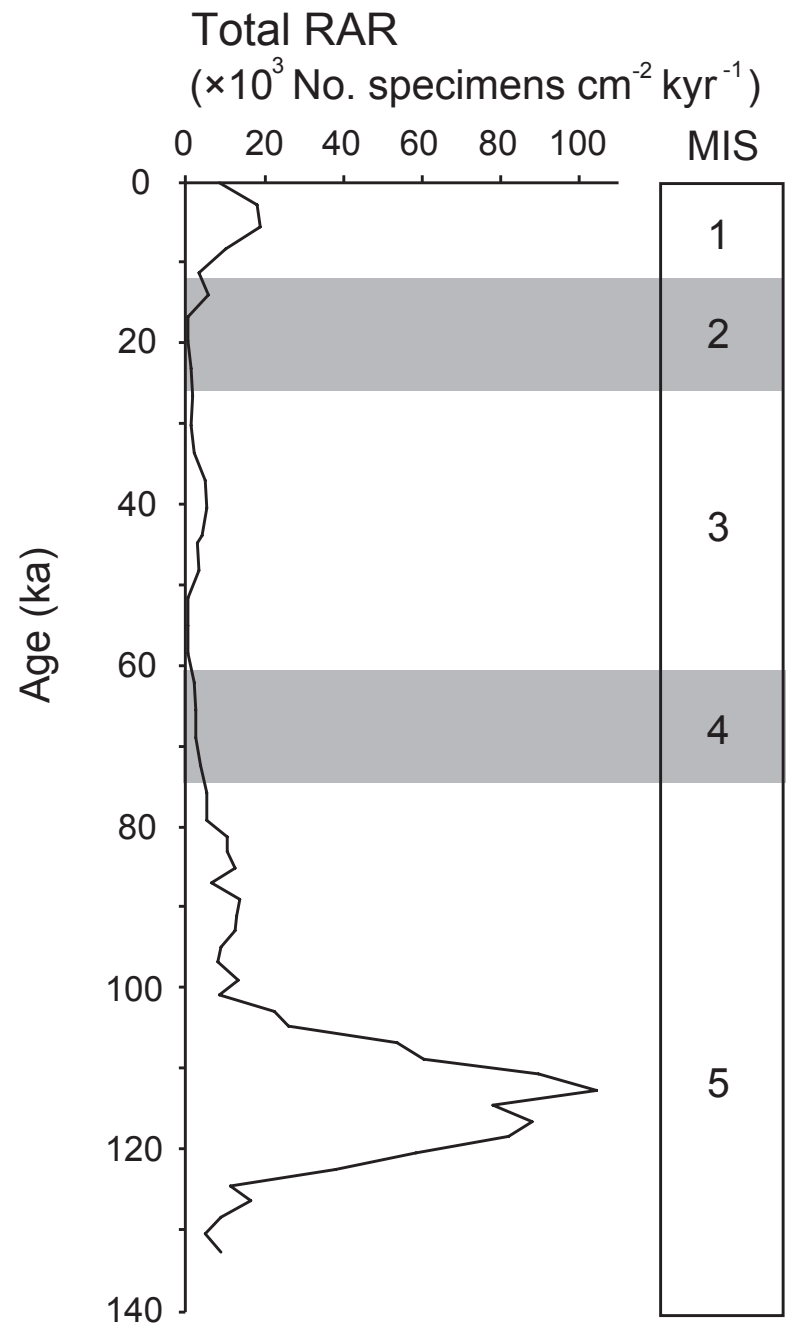

Fig. 3. Changes in total RAR in Core YK07-12 PC3B during the last 130 kyrs. Gray areas indicate cold MIS. 
In this study we focused on two important radiolarian taxa as biostratigraphic markers in the late Pleistocene: Lychnocanoma nipponica (Nakaseko) sakaii (Morley and Nigrini) and Amphimelissa setosa (Cleve) (Fig. 4). They are quite useful markers in the North Pacific and marginal seas (Bjørklund and Swanberg, 1987; Morley et al., 1995; Matul et al., 2002). In Core YK07-12 PC3B, the LO of L. nipponica sakaii occurred in the upper MIS 3 at $25 \mathrm{ka}$, and the L. nipponica sakaii acme event occurred at $81 \mathrm{ka}$ (Table 1, Fig. 5). Our data displayed several differences compared to the results shown by the previous studies. The LO of L. nipponica sakaii in the previous studies are listed in Table 2. Specifically, the LO of L. nipponica sakaii was 49 ka (Morley et al., 1982) and $50 \mathrm{ka}$ (Morley et al., 1995) in the North Pacific. Tanaka and Takahashi (2005) and Itaki et al. (2009) dated the LO of $L$. nipponica sakaii at 46-52 ka using sediment samples from the Bering Sea. Itaki et al. (2007) also estimated the LO to be $54 \mathrm{ka}$ using sediment samples from the Japan Sea. The LO in four piston cores XP98-PC1, XP98-PC2, XP98-PC4, MD01-2412 from the Okhotsk Sea were determined also as ca. 50 ka (Takahashi et al., 2000; Okazaki at al., 2005). The locations of these four core sites are further south of the core site of the present study.
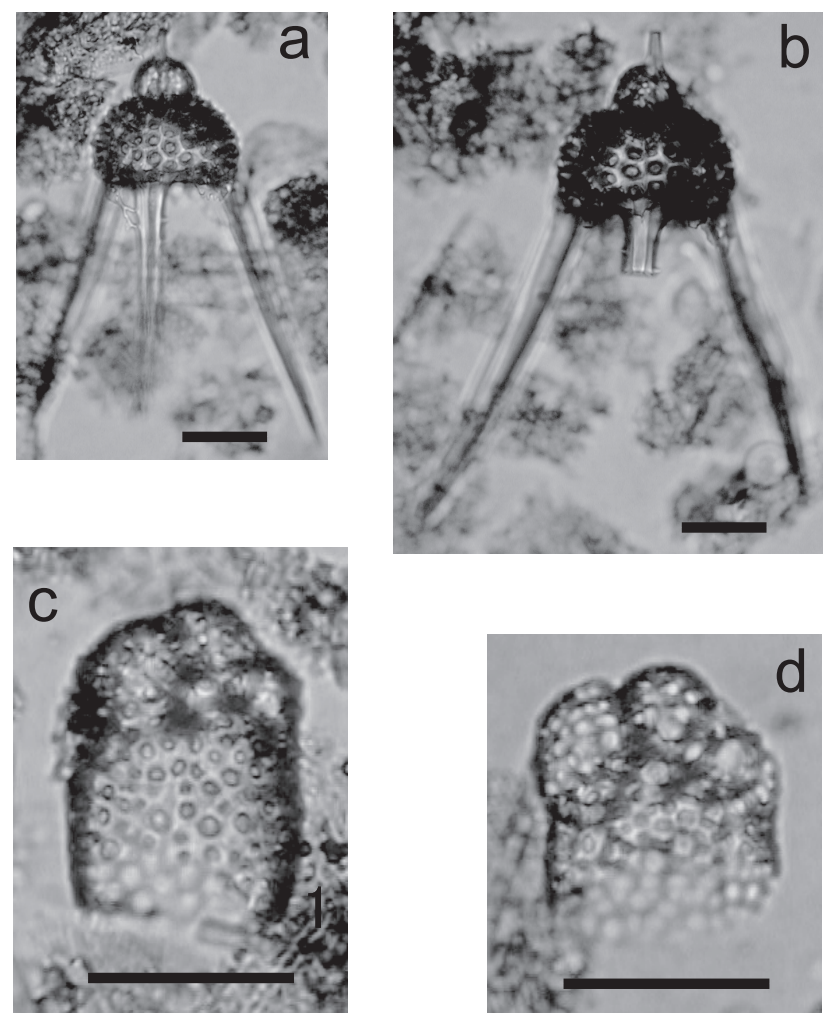

Fig. 4. Radiolarian taxa from Core YK07-12 PC03B discussed in the text. All scale bars equal to $50 \mu \mathrm{m}$. a. Lychnocanoma nipponica (Nakaseko) sakaii (Morley and Nigrini), Sample $230.3 \mathrm{~cm}$. b. Lychnocanoma nipponica (Nakaseko) sakaii (Morley and Nigrini), Sample $230.3 \mathrm{~cm}$. c. Amphimelissa setosa (Cleve), sample $230.3 \mathrm{~cm}$. d. Amphimelissa setosa (Cleve), Sample $230.3 \mathrm{~cm}$.

On the contrary to the majority of the LOs of ca, 50 ka mentioned above, Matul et al. (2002) and Matul et al. (2009) proposed the LO to have occurred at $28 \mathrm{ka}$ and $34 \mathrm{ka}$ in the central Okhotsk Sea, which is fundamentally the same region as that in our study. As mentioned earlier, the results of our study also show that the LO to be at $25 \mathrm{ka}$ level, approximately the same age as those in Matul et al. (2002, 2009). These LOs from the three piston cores (LV28-42-4, MD01-2412, and YK07-12 PC03B) from the same general region collectively displayed significantly younger ages than those from other previous studies. While there is a discrepancy in the timing of the LOs between the older (ca. $50 \mathrm{ka}$ ) and younger (34-25 ka) groups, the overall patterns of the population change with time appear to be conformable between the two groups. Namely, the AR, abundance and relative abundance of L. nipponica sakaii increased steadily from ca. 120 ka towards 50 ka and rapidly declined after 50 


\section{Lychnocanoma nipponica sakaii}

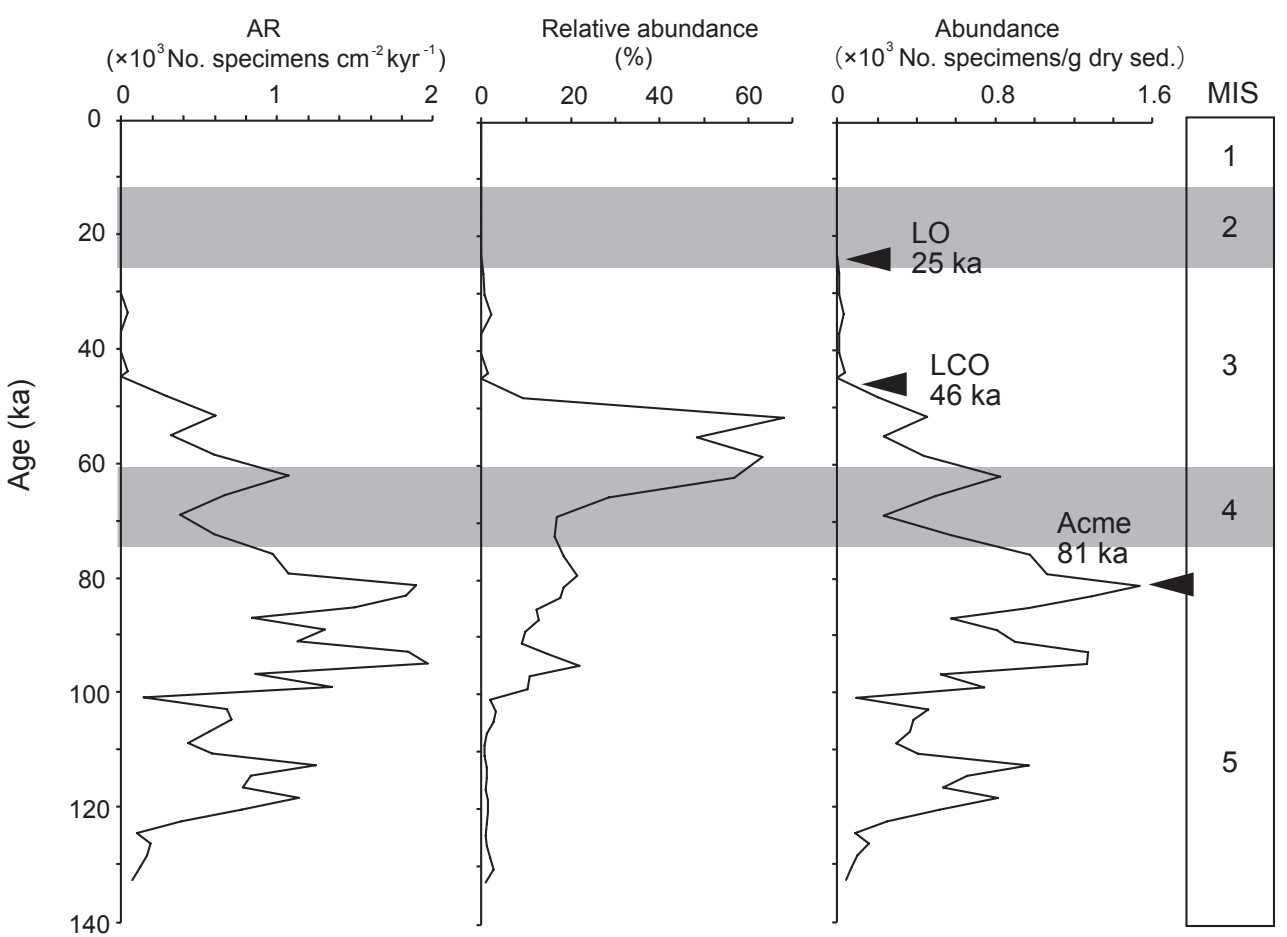

Fig. 5. Changes in AR, relative abundance and abundance of L. nipponica sakaii in Core YK07-12 PC03B. The LO, LCO and Acme datums are shown with arrows.

Amphimelissa setosa

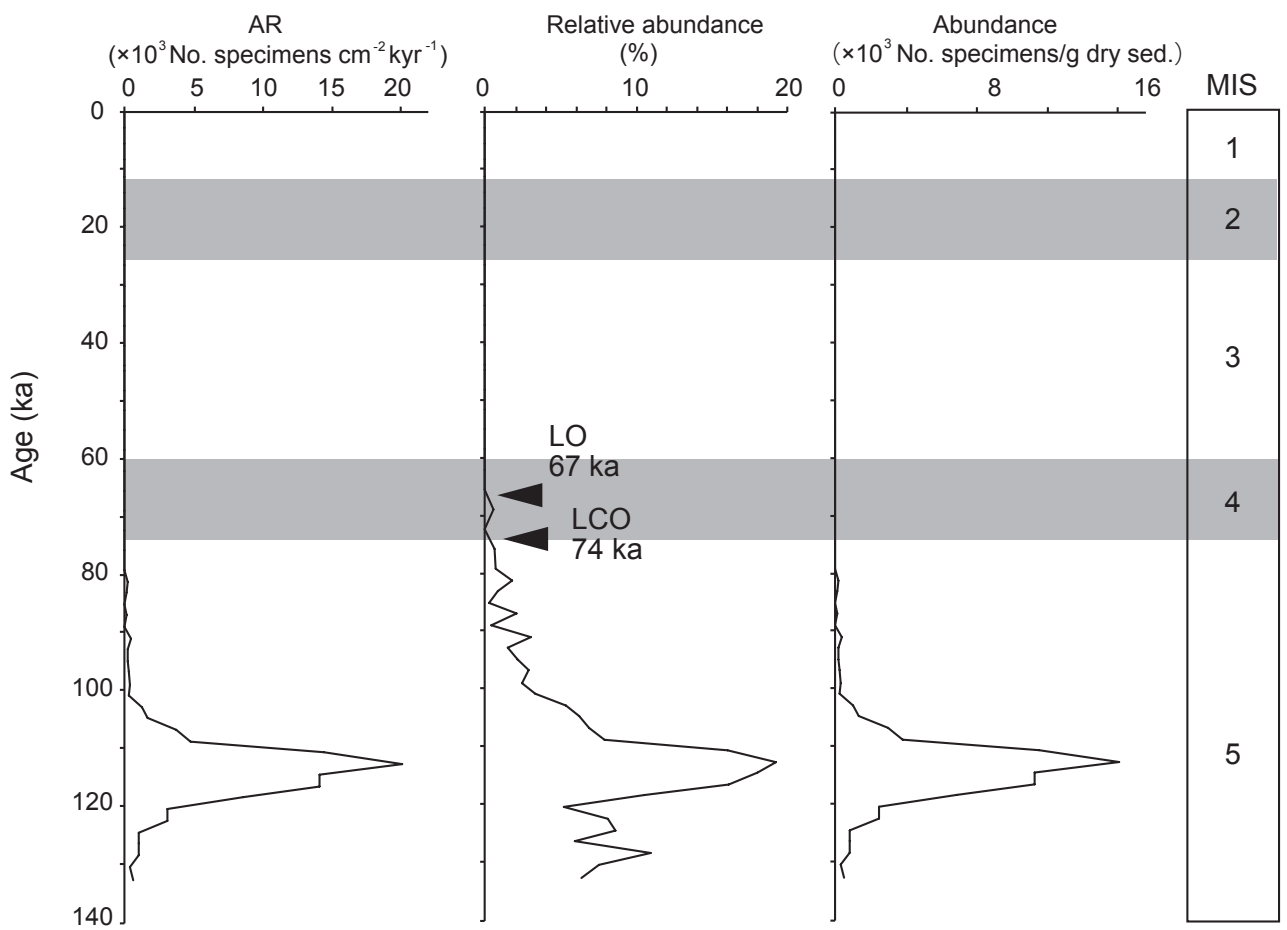

Fig. 6. Changes in AR, relative abundance and abundance of $A$. setosa in Core YK07-12 PC03B. The LO and LCO are shown with arrows. 
ka. Thus, the trend of the changes in AR, abundance and relative abundance in our study are roughly conformable with those in the previous studies.

Furthermore, the LO of $A$. setosa is placed at $67 \mathrm{ka}$ within MIS 4, slightly above the MIS 4/5 boundary (Fig. 6). Thus, the LO of L. nipponica sakaii and A. setosa obtained from Core YK07-12 PC3B correspond to the LOs of Core LV28-42-4 (Matul et al., 2002) fairly well. It is quite possible that the LO of L. nipponica sakaii in the northern part of the central Okhotsk plain is diachronous with respect to the LO of this taxon further south in the Okhotsk plain and in other basins, considering the consistency of the LOs from the same region. It is plausible that the environmental conditions between ca. $50 \mathrm{ka}$ and ca. $34-25 \mathrm{ka}$ in the northern part of the central Okhotsk plain were still favorable for the survival of L. nipponica sakaii whereas those of the further south were severe enough to cause an extinction of this taxon at ca. $50 \mathrm{ka}$. This could well be due to the distribution of the sea-ice cover during the interval in question in the region. It is noteworthy to mention here that the sea-ice cover was more extensive at Site XP98-PC1 than Site XP98-PC2 (Fig. 1), according to Okazaki et al. (2005). Shiga and Koizumi (2000) also reported more open water conditions in the eastern Okhotsk Sea than in the western area during the time period around $22 \mathrm{ka}$ and the last glacial maximum. Based on these pieces of information we interpret that the survival of L. nipponica sakaii was prolonged at our study site than the western area and perhaps further south in the Okhotsk Sea. Thus, one of the possible three reasons (see below for the remainders) for the significantly young $25 \mathrm{ka}$ as the $\mathrm{LO}$ is the diachronous extinction of this taxon within the entire Okhotsk Sea.

As a part of the second explanation of the discrepancy, we herein propose the introduction of "the last common occurrence (LCO)" concept as a practical biostratigraphic datum. This datum should be far more reliable than the LO for the following details which we have encountered in the present piston core. The tail end of the occurrence of L. nipponica sakaii prior to ca. $25 \mathrm{ka}$ (Fig. 5) may well be due to the detailed radiolarian counts performed in our study, which is specifically devoted to illustrate the exact occurrences. Specifically, the total radiolarian counts of 426 ( 4 microslides) at $27 \mathrm{ka}$ and 721 ( 8 microslides) at $30 \mathrm{ka}$ were performed (Table 1). These values are apparently far more greater than those proceeded in other published data whereas their exact counts were not published nor available in their results. Our microscopic counts for L. nipponica sakaii were one specimen at $27 \mathrm{ka}$ and four specimens at $30 \mathrm{ka}$, respectively (Table 1). These relatively small count values could well have been missed and recorded as zeros, had the significantly smaller counts (1 microslide or portion of it) than the present study were made. In that case our LO would have been $46 \mathrm{ka}$ in stead. Thus, it makes a sense to use the $46 \mathrm{ka}$ level as the LCO, which is graphically illustrated as the rapid decrease interval in AR, abundance and $\%$ L. nipponica sakaii.

Table 2.

(a) List of the LO / LCO of L. nipponica sakaii and SR for cores used in the recent studies.

\begin{tabular}{|c|c|c|c|c|c|c|}
\hline Core/ Site & Area & Latitude & Longitude & Age (ka) & $\mathrm{SR}\left(\mathrm{cm} \mathrm{kyr}^{-1}\right)$ & Reference \\
\hline YK07-12 PC03B & Okhotsk Sea & $52^{\circ} 36.01^{\prime} \mathrm{N}$ & $150^{\circ} 08.25^{\prime} \mathrm{E}$ & $25 / 46$ & 2.86 & This paper \\
\hline LV28-42-4 & Okhotsk Sea & $51^{\circ} 42.89^{\prime} \mathrm{N}$ & $150^{\circ} 59.13^{\prime} \mathrm{E}$ & 28 & $2-4$ & Matul et al. (2002) \\
\hline MD01-2415 & Okhotsk Sea & $53^{\circ} 57.09^{\prime} \mathrm{N}$ & $149^{\circ} 57.52^{\prime} \mathrm{E}$ & 34 & $2-4$ & Matul et al. (2009) \\
\hline MD01-2412 & Okhotsk Sea & $44^{\circ} 31^{\prime} \mathrm{N}$ & $145^{\circ} 00^{\prime} \mathrm{E}$ & $47-48$ & 46 & Okazaki et al. (2005) \\
\hline XP98-PC1 & Okhotsk Sea & $51^{\circ} 00.9^{\prime} \mathrm{N}$ & $152^{\circ} 00.5^{\prime} \mathrm{E}$ & $43-44$ & 8.1 & Takahashi et al. (2000) \\
\hline XP98-PC2 & Okhotsk Sea & $50^{\circ} 23.7^{\prime} \mathrm{N}$ & $148^{\circ} 19.4^{\prime} \mathrm{E}$ & $53-55$ & 10.5 & Takahashi et al. (2000) \\
\hline XP98-PC4 & Okhotsk Sea & $49^{\circ} 29.3^{\prime} \mathrm{N}$ & $146^{\circ} 07.7^{\prime} \mathrm{E}$ & $55-56$ & 12.6 & Takahashi et al. (2000) \\
\hline PC-23A & Bering Sea & & & 48.6 & & Itaki et al. (2009) \\
\hline ES & Bering Sea & & & 45.9 & & Tanaka and Takahashi (2005) \\
\hline BOW-8A & Bering Sea & & & 49.5 & & Tanaka and Takahashi (2005) \\
\hline BOW-9A & Bering Sea & & & 49.7 & & Tanaka and Takahashi (2005) \\
\hline BOW-12A & Bering Sea & & & 51.7 & & Tanaka and Takahashi (2005) \\
\hline MD01-2407 \& others & Japan Sea & & & 54 & & Itaki et al. (2007) \\
\hline V20-120, RC14-103 \& others & North Pacific & & & 49 & & Morley et al. (1982) \\
\hline ODP Sites 881,883 \& others & North Pacific & & & 50 & & Morley et al. (1995) \\
\hline
\end{tabular}

(b) List of the LO / LCO of A. setosa and SR for cores used in the recent studies.

\begin{tabular}{|c|c|c|c|c|c|c|}
\hline Core/ Site & Area & Latitude & Longitude & Age (ka) & $\mathrm{SR}\left(\mathrm{cm} \mathrm{kyr}^{-1}\right)$ & Reference \\
\hline YK07-12 PC03B & Okhotsk Sea & $52^{\circ} 36.01^{\prime} \mathrm{N}$ & $150^{\circ} 08.25^{\prime} \mathrm{E}$ & $67 / 74$ & 2.86 & This paper \\
\hline LV28-42-4 & Okhotsk Sea & $51^{\circ} 42.89^{\prime} \mathrm{N}$ & $150^{\circ} 59.13^{\prime} \mathrm{E}$ & 72 & $2-4$ & Matul et al. (2002) \\
\hline MD01-2415 & Okhotsk Sea & $53^{\circ} 57.09^{\prime} \mathrm{N}$ & $149^{\circ} 57.52^{\prime} \mathrm{E}$ & 64 & $2-4$ & Matul et al. (2009) \\
\hline ES & Bering Sea & & & 85.1 & & Tanaka and Takahashi (2005) \\
\hline BOW-8A & Bering Sea & & & 111.5 & & Tanaka and Takahashi (2005) \\
\hline BOW-9A & Bering Sea & & & 68 & & Tanaka and Takahashi (2005) \\
\hline \multirow[t]{2}{*}{ GAT-3A } & Bering Sea & & & 82.6 & & Tanaka and Takahashi (2005) \\
\hline & North Pacific & & & 70 & & Bjørklund and Swanberg (1987) \\
\hline
\end{tabular}


As a second alternative, the slow SR observed in the central Okhotsk Sea may have caused the discrepancy in the LO levels. Itaki et al. (2009) speculated that the delay of the LO of L. nipponica sakaii by Matul et al. (2002) might be due to the effect of bioturbation in the slow SR environment. When sedimentation rates are slow fossil radiolarian specimens initially located at several $\mathrm{cm}$ deep (or even deeper sometimes) in sediments, for example, could have been subsequently transported upward to the sediment surface or nearby by organisms living near the surface or within sediments, causing a bioturbation. Such an activity can alter the sequentially deposited initial signature in a drastic manner. On the other hand, the chances of the effect in high SR regime can minimize such an action because faster burial than the artifact of the bioturbation. The sedimentation rates of the previously studied cores from the Okhotsk Sea are shown in Table 2. The sediment cores with higher SRs than the three piston cores (LV28-42-4, MD01-2412, and PC03B) may have led the LO of L. nipponica sakaii to be ca. $50 \mathrm{ka}$. Thus, the time lag of the LO of L. nipponica sakaii with respect to the LCO in YK07-12 PC03B could possibly be due to the effect of bioturbation in the slow SR regime. Note that the first disappearances of L. nipponica sakaii and A. setosa after the major occurrence maxima are $46 \mathrm{ka}$ and $74 \mathrm{ka}$, respectively. These ages are nearly equal to the LO of other previously published studies. One drawback of such an explanation with the slow SR is that the LO of $A$. setosa at $68 \mathrm{ka}$ did not cause any significant time lag compared to the data from the fast SR regimes. Because that the occurrence of total radiolarians is about the same at both at $25 \mathrm{ka}$ and $67 \mathrm{ka}$ (Table 1, Fig. 3) it is difficult to explain why we did not encounter a time lag problem in the LO of $A$. setosa in the present piston core.

\section{Conclusions}

A focused detailed study on two important radiolarian biostratigraphic markers of the late Pleistocene was performed in the northern part of the central Okhotsk plain: Lychnocanoma nipponica (Nakaseko) sakaii (Morley and Nigrini) and Amphimelissa setosa (Cleve). We have employed Core YK07-12 PC3B from the northern part of the central Okhotsk plain with the aid of benthic foraminiferal $\delta^{18} \mathrm{O}$ stratigraphy. The introduction of the concept of "the last common occurrence (LCO)" makes a sense where the LO and the LCO differ significantly in age, especially in the case of the present study. The LCO of the $46 \mathrm{ka}$ in the present study serves as a comparable datum with respect to the LO at ca. $50 \mathrm{ka}$ of L. nipponica sakaii found further south in the Okhotsk Sea and elsewhere in the marginal seas of the North Pacific and subarctic Pacific. It is possible that the extinction datum of L. nipponica sakaii in the northern part of the central Okhotsk plain $(25 \mathrm{ka})$ specifically lagged behind of that of elsewhere by ca. 25 kyrs. This may well have caused the diachronous LO compared to those of elsewhere. We interpret that the sea-ice conditions were favorable to allow the survival of $L$. nipponica sakaii for additional ca. 16-25 kyrs in the study region compared to elsewhere. As alternative explanations for the discrepancy in the LOs, we also offer (1) the detailed counts of the radiolarians in this devoted study; and (2) the slow SR where bioturbation may have caused the apparent time lag of the LO at $25 \mathrm{ka}$ compared to the $\mathrm{LO}$ of ca. $50 \mathrm{ka}$ in the studies performed other than in the northern part of the central Okhotsk plain. Furthermore, the LO of Amphimelissa setosa at $67 \mathrm{ka}$ obtained from the present study was conformable with that of Core LV28-42-4.

\section{Acknowledgments}

We thank scientists, Captain and crew participated in Cruise YK07-12 of R/V Yokosuka who assisted us on board for this work. We thank Dr. Yusuke Okazaki of JAMSTEC for his constructive review of an early draft of this paper as well as further discussion. The senior author received and benefitted by the Professor Tatsuro Matsumoto Scholarship Fund.

\section{References}

Bjørklund, K.R., and Swanberg, N.R. (1987) The distribution of two morphotypes of the radiolarian Amphimelissa setosa Cleve (Nassellarida): a result of environmental variability. Sarsia, 72, 245-254.

Bjørklund, K.R., Cortese, G., Swanberg, N., and Schrader, H.J. (1998) Radiolarian faunal provinces in surface sediments of the Greenland, Iceland and Norwegian (GIN) Seas. Marine Micropaleontology, 35, 105-140.

Itaki, T. (2003) Elutriation technique for the extraction of radiolarian skeletons from sandy sediment. Fossils, 73, 
$38-41$.

Itaki, T., Komatsu, N., and Motoyama, I. (2007) Orbital- and millennial-scale changes of radiolarian assemblages during the last 220 kyrs in the Japan Sea. Palaeogeography, Palaeoclimatology, Palaeoecology, 247, 115-130.

Itaki, T., Uchida, M., Kim, S., Shin, H-S., and Tada, R. (2009) Late Pleistocene stratigraphy and palaeoceanographic implications in northern Bering Sea slope sediments: evidence from the radiolarian species Cycladophora davisiana. Journal of Quaternary Science, 24, 856-865.

Lisiecki. L.E., and Raymo, M.E., 2005. A Plio-Pleistocene stack of 57 globally distributed benthic $\delta^{18} \mathrm{O}$ records. Paleoceanography, 20, 1003.

Morley, J.J., and Nigrini, J.D. (1995) Miocene to Pleistocene radiolarian biostratigraphy of North Pacific sites 881, 884, 885, 886, and 887. In: Rea, D.K., Basov, I.A., Scholl, D.W., Allan, J.F. (Eds.), Proc. ODP, Sci. Results, 145, College Station, TX (Ocean Drilling Program), 55-91.

Morley, J.J., Hays, J.D., and Robertson, J.H. (1982) Stratigraphic framework for the late Pleistocene in the northwest Pacific Ocean. Deep-Sea Research, 29, 1485-1499.

Morley, J.J., Tiase, V.L., Ashby, M.M., and Kashgarian, M. (1995) A high-resolution stratigraphy for Pleistocene sediments from North Pacific Sites 881, 883, and 887 based on abundance variations of the radiolarian Cycladophora davisiana. In: Rea, D.K, Basov, I.A, Scholl D.W., Allen, J.F. (Eds), Proc. ODP, Sci. Results, 145, College Station, TX (Ocean Drilling Program), 133-140.

Matul, A., Abelmann, A., Tiedemann, R., Kaiser, A., and Nürnberg, D. (2002) Late Quaternary polycystine radiolarian datum events in the Sea of Okhotsk. Geo-Marine Letters, 22(1), 25-32.

Matul, A., Abelmann, A., Nürnberg, D., and Tiedemann, R. (2009) Stratigraphy and major paleoenvironmental changes in the Sea of Okhotsk during the last million years inferred from radiolarian data. Oceanology, 49(1), 93-100.

Okazaki, Y., Takahashi, K., Yoshitani, H., Nakatsuka, T., Ikehara, M., and Wakatsuchi, M. (2003) Radiolarians under the seasonally sea-ice covered conditions in the Okhotsk Sea: flux and their implications for paleoceanography. Marine Micropaleontology, 49(3), 195-230.

Okazaki, Y., Takahashi, K., Katsuki, K., Ono, A., Hori, J., Sakamoto, T., Uchida, M., Shibata, Y., Ikehara, M., and Aoki, K. (2005) Late Quaternary paleoceanographic changes in the southwestern Okhotsk Sea: evidence from geochemical, radiolarian, and diatom records. Deep-Sea Research II, 52, 2332-2350.

Shiga, K., and Koizumi, I., (2000) Latest Quaternary oceanographic changes in the Okhotsk Sea based on diatom records. Mar. Micropaleontol. 38, 91-117.

Takahashi, K. (1998) The Bering and Okhotsk Seas: modern and past paleoceanographic changes and gateway impact. Journal Asian Earth Science, 16, 49-58.

Takahashi, K., Okazaki, Y., and Yoshitani, H. (2000) Radiolarian fossils and paleoceanography: accumulation changes in the Okhotsk Sea. Chikyu Monthly. 22, 623-630. [in Japanese]

Talley, L. D. (1991) An Okhotsk Sea water anomaly: implications for ventilation in the North Pacific. Deep-Sea Research, 38, S171-S190.

Tanaka, S. and Takahashi, K. (2005) Late Quaternary paleoceanographic changes in the Bering Sea and the western subarctic Pacific based on radiolarian assemblage. Deep-Sea Research II, 52, 2131-2149. 